JURNAL SOSIAL-EKONOMI PERTANIAN DAN AGRIBISNIS

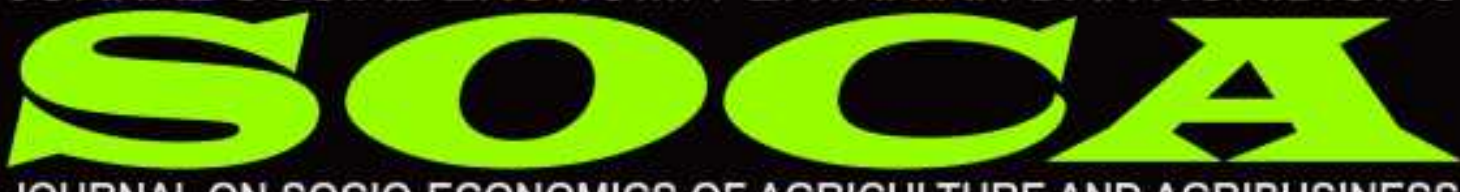

JOURNAL ON SOCIO-ECONOMICS OF AGRICULTURE AND AGRIBUSINESS

\title{
MODAL SOSIAL ANGGOTA KELOMPOK TANI GEMAHRIPAH DALAM MENGATASI HAMA DAN PENYAKIT TANAMAN DI DESA WIROWONGSO KECAMATAN AJUNG KABUPATEN JEMBER
}

\author{
Sofian Ardiansyah, Triwila Nindra Putra Perdana dan Ferdiansyah Adi Permana \\ Universitas Jember, Jember, Jawa Timur \\ E-mail : ardiansyah.21@gmail.com,ntriwila@gmail.com dan \\ ferdiansyahadipermana@gmail.com \\ HP: 081459080113,081233033310 dan 085804820234
}

\begin{abstract}
ABSTRAK
Sektor pertanian saat ini kerap menjadi perhatian serius oleh pemerintah, hal ini dikarenakan banyak masalah yang kerap kali menyerang sektor pertanian. Permasalahan utama yang kerap kali menjadi gangguan pada sektor pertanian yaitu permasalahan hama dan penyakit. Penelitian ini bertujuan untuk mengetahui modal sosial anggota kelompok tani Gemahripah dalam menghadapi permasalahan hama dan penyakit tanaman di Desa Wirowongso, Kecamatan Ajung, Kabupaten Jember. Metode penentuan daerah penelitian pada penelitian ini menggunakan purposive method. Metode penelitian menggunakan analisis kualitatif dan studi kasus. Metode pengumpulan data menggunakan metode wawancara, observasi dan dokumentasi untuk mendapatkan data primer dan sekunder. Analisis data menggunakan model analisis Miles dan Huberman mulai dari pengumpulan data, reduksi data, penyajian data dan kesimpulan/verifikasi. Hasil penelitian menunjukkan bahwa terdapat 5 unsur utama modal sosial anggota kelompok tani Gemahripah dalam mengatasi permasalahan hama dan penyakit tanaman antara lain partisipasi dalam jaringan, respirocity/timbal balik, trust/kepercayaan, norma sosial dan nilai-nilai.
\end{abstract}

Kata Kunci: Modal sosial, Kelompok Tani, Hama dan penyakit, Kios Pertanian

\section{SOCIAL CAPITAL OF MEMBERS GEMAHRIPAH FARMER GROUP FOR SOLVING PLANT PESTS AND DISEASES IN WIROWONGSO VILLAGE AJUNG DISTRICT JEMBER REGENCY}

\begin{abstract}
The agricultural sector is currently often a serious concern by the government, this is due to the many problems that often attack the agricultural sector. The main problems that often become disruptions to the agricultural sector are the problems of pests and diseases. The goal of this research is to determine the social capital of members of the
\end{abstract}


Gemahripah farmer group for solving plant pest and disease problems in Wirowongso Village, Ajung District, Jember Regency. The method of determining the research location in this research uses purposive method. The research method uses qualitative analysis and case studies. The method of data collection uses the method of interviews, observation and documentation to obtain primary and secondary data. Data analysis used the Miles and Huberman analysis models starting from data collection, data reduction, data presentation and conclusions / verification. The results showed that there were 5 main elements of social capital of members of the Gemahripah farmer group for solving the problems of pests and plant diseases, including participation in networks, respirocity, trust, social norms and values.

Keyword: Social Capital, Farmer Group, Plant Pests and Diseases, Agricultural store

\section{PENDAHULUAN}

Sektor pertanian saat ini kerap menjadi perhatian serius oleh pemerintah, hal ini dikarenakan banyak masalah yang kerap kali menyerang sektor pertanian sehingga menimbulkan dampak negatif terhadap sektor lain. Permasalahan utama yang kerap kali menjadi gangguan pada sektor pertanian yaitu permasalahan hama dan penyakit. Permasalahan hama dan penyakit merupakan hal yang sering dibicarakan dalam kegiatan budidaya pertanian, hal ini dikarenakan hama dan penyakit selalu dianggap musuh bagi petani dalam kegiatan produksi. Serangan hama dan penyakit menyebabkan keresahan kepada petani. Usaha pengendalian perlu dilakukan agar terhindar dari kehilangan hasil dan mampu menjamin tercapainya produksi maksimal, kendala utama terletak pada ketidaktahuan petani terhadap ciri-ciri atau gejala serangan hama dan penyakit menyebabkan petani kerap kali mengabaikan permasalahan hama dan penyakit ini. Kelompok tani diharuskan memiliki andil besar dalam penyebaran informasi terkait permasalahan hama (Suryanto, 2010) .
Menurut (Wastika, Hariadi, Pertanian, \& Gadjah, 2014) kelompok tani dapat digunakan sebagai wadah bagi orang-orang yang memiliki keterikatan, nasib dan tujuan yang sama. Kelompok tani merupakan aspek penting yang perlu diperhitungkan untuk penyebaran informasi. Kelembagaan pertanian khususnya kelompok tani perlu didorong guna memberikan kontribusi dalam penyelesaian masalah pertanian. Pengembangan kelompok tani bukan suatu hal yang mudah, banyak sekali tantangan atau kendala yang cenderung menghambat kinerja kelompok tani. Perhatian pemerintah saat ini hanya terfokus pada peningkatan produksi, sehingga permasalahan kelompok tani kerap kali dikesampingkan, hal ini cenderung buruk karena pada dasarnya dalam penerapan program atau pengentasan permasalahan yang ada di lapang harus didahului dengan penguatan kelembagaan, ketika kelembagaan atau kelompok tani tersebut kuat secara otomatis program yang diberikan pemerintah akan terserap dengan mudah, maka dari itu perlu terlebih dahulu membangun kepercayaan petani melalui penguatan kelompok tani. Lemahnya kelompok 
tani cenderung akan menghambat arus informasi baik dari dalam atau luar kelompok.

Pembangunan kepercayaan kelompok tani didasarkan pada modal sosial petani-petani yang ada di dalamnya. Modal sosial merupakan pondasi dalam pengembangan kelompok tani, hal ini dikarenakan modal sosial berperan penting dalam membangun integarsi sosial serta menjadi perekat sosial di masyarakat khususnya para petani yang tergabung pada kelompok tani. Putnam (1995) di dalam Margadinata (2017) (Luciana et al., 2017) berpendapat bahwa modal sosial pada dasarnya merupakan hasil dari kepercayaan dan norma-norma berasal antar pelaku dalam struktur sosial. Modal sosial adalah salah satu komponen utama dalam menggerakkan kebersamaan, mobilitas ide, kesalingpercayaan dan saling menguntungkan untuk mencapai kemajuan bersama. Putnam menjabarkan modal sosial sebagai seperangkat asosiasi antar manusia yang bersifat horizontal yang mencakup jaringan dan norman bersama yang berpengaruh terhadap produktivitas suatu masyarakat. Putnam juga melihat modal sosial meliputi hubungan sosial, norma sosial dan (trust) kepercayaan, penekanan modal sosial yaitu untuk membangun jaringan (network) dan adanya pemahaman norma namun perlu disadari pemahaman norma belum cukup menjamin kerjasama antar individu karena bisa saja ada yang tidak taat (moral hazard,) oleh karena itu dibutuhkan sanksi sosial yang bersifat informal untuk menjaga kualitas hubungan dan interaksi sosial di dalam masyarakat.
Modal sosial juga merupakan seperangkat "hubungan horisontal" antara orang-orang yang berpengaruh pada produktivitas komunitas. konsep model sosial adalah kepercayaan dan kerjasama, seperti yang dinyatakan oleh Fukuyama (1995) sebagai kerjasama berdasarkan kelaziman kepercayaan. Bila kepercayaan dan keyakinan mendominasi individu dan kelompok, maka akan memungkinkan untuk menciptakan kehidupan yang bertanggung jawab antar sesama manusia sehingga dapat bertindak secara bertanggung jawab dan akan memperkuat solidaritas kelompok, dengan kekuatan yang dimiliki oleh kepercayaan dan kerjasama antar individu dan kelompok, maka modal sosial berdasarkan pada kepercayaan akan mengubah kemampuan individu menjadi kemampuan kelompok (Soepriadi, 2014)

Menurut Prasetya dalam Kimbal (2015) modal sosial terdiri dari beberapa unsur yang dapat mengidentifikasi kerjasama yang dilakukan secara kelompok. Unsurunsur modal sosial antara lain partisipasi dalam jaringan, respirocity, trust, norma sosial, nilai-nilai dan tindakan pro aktif. Modal sosial melekat pada struktur hubungan antara pelaku yang mana keterlibatan norma-norma dan jaringan dalam masyarakat khususnya petani berpengaruh kuat dalam mempengaruhi kinerja kelompok tani, secara kelembagaan pengelolaan akan lebih efektf jika terdapat kepemilikan modal sosial yang tinggi, sebaliknya rendahnya modal sosial yang dimiliki oleh petani akan berdampak buruk terhadap kelompok tani (Trisnanto, Fitriani, \& Fatih, 2017) .

Pengembangan modal sosial petani sangat diperlukan untuk 
membangun kelompok tani yang ada di wilayah-wilayah. Kecamatan Ajung Kabupaten Jember merupakan salah satu wilayah yang perlu dikembangkan kelompok taninya, mengingat di Kecamatan Ajung saat ini penggunaan lahan masih tergolong memiliki potensi untuk dimanfaatkan. Kecamatan Ajung terletak bagian selatan Kabupaten Jember yang mana memiliki berbagai potensi khsususnya pada sektor pertanian. Potensi tersebut salah satunya masih memiliki jumlah luas lahan sawah yang tergolong masih banyak.

Desa Wirowongso merupakan salah satu desa dari 7 desa yang berada di Kecamatan Ajung. Desa Wirowongso terletak di bagian selatan Kecamatan Ajung dan merupakan salah satu desa yang letaknya paling dekat dengan daerah perkotaan, meskipun jarak dengan daerah kota tidak terlalu jauh, tetapi daerah persawahan yang ada di sana masih tergolong banyak dan masyarakat di sana mayoritas masih bergantung kepada sektor pertanian. Komoditas mayoritas yang ditanami petani yaitu komoditas padi dan jagung, Kendala penguasaan lahan dan alih fungsi lahan menjadi permasalahan yang menghambat produktivitas. Penguasaan lahan di Desa Wirowongso cenderung tidak seimbang hal ini karena lahan yang ada di wirowongso dikuasai oleh beberapa orang yang bekerja di perusahaan, yang mana oleh orang tersebut disewakan kepada petani, dengan lahan sewa tersebut petani cenderung berkeinginan berproduksi dengan optimal. Desa Wirowongso terbagi menjadi beberapa dusun antara lain Dusun Besuk, Lenes, dan Pananggungan yang didalamnya terdapat 3 kelompok tani yaitu Tirto ayu, Karya tani dan Gemahripah. Kelompok-kelompok tani tersebut cenderung tidak aktif, dan jarang melakukan perkumpulan ataupun penyuluhan. Perkumpulan hanya dilakukan ketika ada program pemerintah seperti bantuan dan lainnya. Permasalahan ini menjadikan petani cenderung menghadapi permasalahan secara individu dan lebih percaya terhadap stakeholder yang berada di luar desa.

Kelompok tani Gemahripah merupakan salah satu kelompok tani yang masih tergolong aktif karena masih kerap kali berkumpul meskipun dilakukan di desa lain, beberapa tahun terakhir Kelompok Tani Gemahripah mengalami penurunan keaktifan, hal ini dikarenaka sebagian besar anggota kelompok tidak memiliki lahan tetap atau melakukan sewa lahan dalam melakukan usaha tani, ketika lahan garapan habis masa sewanya dan tidak diperpanjang, petani tersebut terpaksa keluar dari kelompok, hal ini mengakibatkan keanggotaan Kelompok Tani Gemahripah menjadi tidak tetap dan menyulitkan dalam koordinasi ataupun pertemuan. Turunya keaktifan ini menyebabkan anggota Kelompok Tani Gemahripah sulit menerima informasi Permasalahan hama dan penyakit tanpa adanya solusi dari penyuluh atau dari dalam kelompok tani memaksa beberapa anggota untuk menyelesaikan permasalahannya secara individu dan mempercayai stakeholder luar yaitu kios pertanian yang berada di luar desa yaitu berada di Desa Rowoindah, beberapa petani yang tergabung di kelompok tani Gemahripah ketika mendapatkan permasalahan baik serangan hama penyakit serta pemenuhan kebutuhan input lebih 
bergantung kepada kios pertanian tersebut. Modal sosial petani cukup tinggi terhadap pemilik kios tersebut sehingga petani memilih membeli input baik itu pestisida, insektisida dan pupuk di kios yang tergolong berada di luar desa dan jarak yang ditempuh lebih jauh, bahkan ketika terdapat gejala serangan hama petani langsung bertanya atau menelfon pemiliki kios dan menanyakan solusi terhadap serangan hama dan penyakit tersebut.

Permasalahan-permasalahan

hama dan penyakit merupakan masalah yang juga kerap kali muncul pada anggota kelompok tani Gemahripah dengan adanya permasalahan hama dan penyakit, petani cenderung mengandalkan modal sosial yaitu kepercayaan mereka kepada stakeholder luar yaitu kios pertanian di Desa Rowoindah dibanding di dalam desa baik itu dari kelompok tani ataupun penyuluh dalam mengatasi permasalahan. Berdasarkan fenomena tersebut peneliti ingin meneliti mengenai modal sosial anggota kelompok Gemahripah dalam mengatasi hama dan penyakit tanaman serta tindakan petani dalam mengatasi permasalahan hama dan penyakit setelah memilih percaya pada stakeholder luar (kios pertanian) di Desa Wirowongso Kecamatan Ajung. Penelitian yang dilakukan penting untuk dilakukan karena dapat melihat bagaimana modal sosial anggota kelompok Gemahripah yang digunakan untuk mengatasi berbagai masalah yang ada, sehingga dapat bermanfaat bagi petani dalam penambahan wawasan modal sosial untuk mengatasi masalah yang ada.

\section{METODE PENELITIAN}

Penentuan daerah penelitian menggunakan purposive method yaitu metode yang digunakan untuk memilih daerah penelitian secara sengaja (purposive method). Menurut Rianse dan Abdi (2012), purposive method merupakan teknik penentuan daerah penelitian yang dilakukan secara sengaja oleh peneliti dengan indikator atau pertimbangan yang telah ditentukan sebelumnya. Penelitian ini dilaksanakan di Desa Wirowongso Kecamatan Ajung Kabupaten Jember dengan mempertimbangkan aspek potensial Desa Wirowongso yang notabene dekat dengan daerah perkotaan tetapi masih memiliki potensi dalam sektor pertanian. Penenentuan daerah penelitian di Desa Wirowongso pada dasarnya juga untuk menjawab permasalahan-permasalahan yang ada, salah satunya serangan hama dan penyakit pada tanaman. Pengentasan hama dan penyakit yang menyerang dilakukan secara individu, hal ini diakibatkan kelompok tani yang menurun keaktifanya. Penurunan keaktifan kelompok tani berdampak pada pencarian informasi mengenai permasalahan hama penyakit dilakukan secara mandiri oleh petani dan lebih percaya terhadap stakeholder (kios pertanian) yang berada di luar desa dibanding di dalam desa.

Penelitian ini dilakukan dengan metode analisis kualtatif dan studi kasus (case study). Menurut Gumilang (2016) definisi penelitian kualitatif secara umum yaitu merupakan suatu metode berganda dalam fokus, yang melibatkan suatu pendekatan interpretatif dan wajib terhadap setiap pokok permasalahan, salah satu 
pendekatan atau metode dalam penelitian kualitatif adalah studi kasus. Studi kasus merupakan uraian dan penjelasan komperhensif mengenai berbagai aspek individu, kelompok, organisasi, program, situasi sosial dan sebagainya. Pendekatan studi kasus cenderung memusatkan perhatian pada suatu kasus secara intensif dan rinci. Indikator dipilihnya penelitian studi kasus antara lain, guna mendapatkan saran utama bagi penelitian yang bersifat emik (menyajikan pandangan subyek yang diteliti), diharapkan dapat memberikan uraian secara menyeluruh yang mirip dengan yang diuraikan pembaca dalam kehidupan sehari-hari, dapat berguna sebagai sarana efektif untuk menunjukkan hubungan antara peneliti dengan responden atau subyek penelitian dan juga diharapkan dengan menggunakan studi kasus memungkinkan pembaca untuk menemukan konsistensi, internal, gaya, dan faktual dengan subyek penelitian serta bisa membangun kepercayaan

(trustworthiness)

(Suwendra, 2018)

Metode penelitian analisis kualitatif dan studi kasus dilakukan searah dengan rumusan masalah serta pertanyaan penelitian atau bisa dikatakan identifikasi permasalahan mengenai situasi sosial yang ada. Metode penelitian analisis kualitatif studi kasus dilakukan secara deskriptif dengan tujuan agar penelitian ini mampu memberikan gambaran secara jelas serta pemahaman yang mendalam dan menyeluruh mengenai modal sosial yang dilakukan oleh anggota kelompok tani Gemahripah dalam mengatasi permasalahan hama dan penyakit tanaman.
Informan pada penelitian ini dipilih dengan teknik purposive sampling. Menurut Yusuf (2014) purposive sampling cenderung berbeda dengan cara-cara penentuan sampel yang lain, pada purposive sampling penentuan sumber informasi atau informan dilandasi tujuan dan pertimbangan tertentu telebih dahulu. Purposive dapat diartikan sebagai maksud, tujuan dan kegunaan. Tujuan digunakannya teknik purposive sampling yaitu untuk menentukan informan awal atau yang biasa disebut key informan. Indikator pemilihan purposive sampling yaitu guna menghindari kesalahan pemilihan informan, jadi harus ditentukan secara sengaja sesuai dengan kriteria yang dibutuhkan. Penentuan informan dengan menggunakan metode ini memliki beberapa kriteria umum dan kriteria khusus. Menurut Sugiarto (2015), penentuan informan sebagai sumber data setidaknya memenuhi beberapa kriteria sebagai berikut:

1. Mereka yang menguasai atau memahami sesuatu melalui proses enkulturasi, sehingga sesuatu itu bukan hanya diketahui tetapi juga didalami.

2. Mereka yang tergolong masih sedang berkecimpung atau terlibat pada kegiatan yang sedang diteliti.

3. Mereka yang mempunyai waktu yang memadai untuk dimintai informasi.

4. Mereka yang tidak cenderung menyampaikan informasi berdasarkan hasil "kemasannya" sendiri.

5. Mereka yang pada mulanya tergolong "cukup asing" dengan peneliti sehingga lebih tepat 
untuk dijadikan sebagai narasumber.

Penambahan informan akan dihentikan ketika data yang dikumpulkan telah jenuh. Artinya, informasi yang dikumpulkan baik dari informan lama maupun baru tidak dapat memberikan informasi baru lagi. Berdasarkan kriteria umum di atas, maka dapat ditarik beberapa kriteria khusus yang harus dipenuhi dalam penentuan informan pada penelitian ini. Kriteria khusus tersebut antara lain:

1. Informan merupakan mereka yang berpartisipasi atau mempercayai kios pertanian dalam mengatasi permasalahan hama dan penyakit tanaman di Desa Wirowongso.

2. Informan merupakan mereka yang mampu memberikan penjelasan yang rinci dan akurat mengenai unsur-unsur modal sosial terkait kepercayaan anggota kelompok tani Gemahripah dalam mengatasi permasalahan hama dan penyakit tanaman.

Berdasarkan kriteria-kriteria tersebut, penentuan informan untuk pengumpulan data dan informasi pada penelitian ini terbagi menjadi 2 yaitu informan kunci dan informan pendukung. Proses pembagian tersebut mengahsilkan 2 informan yang terdiri dari 1 informan kunci dan 1 informan pendukung, keterlibatan informan-informan tersebut dijelaskan sebagai berikut :

1. Ketua Kelompok Tani Gemahripah sebagai informan kunci, dipilih dengan pertimbangan yaitu karena ketua dari kelompok tani Gemahripah ikut serta dan lebih percaya terhadap kios pertanian yang berada di Rowo Indah. Informasi yang diperoleh dari ketua kelompok tani Gemahripah yaitu mengenai peran modal sosial dan tindakan dari ketua kelompok tani dalam mengatasi permasalahan hama dan penyakit tanaman.

2. Anggota kelompok tani Gemahripah terlibat sebagai informan pendukung yang dipilih atas kriteria karena memilih percaya kepada toko pertanian yang ada diluar desa dalam menyelesaikan permasalahan hama dan penyakit. Informasi yang diperoleh yaitu peran modal sosial dan tindakan anggota kelompok tani Gemahripah dilihat dari sudut pandang informan pendukung.

Penentuan informan ini nantinya dapat bertambah seiring dengan bertambahnya informasi baru dari informan hingga informasi mengenai pelaksanaan dan proses adopsi inovasi yang dikumpulkan telah jenuh.

Metode pengumpulan data yang digunakan dalam penelitian ini dilakukan antara lain yaitu wawancara secara mendalam, observasi pasif dan Dokumentasi yang dijelaskan sebagai berikut :

1. Wawancara Mendalam

Menurut West and Turner yang diterjemahkan oleh Maer (2008), metode wawancara mendalam (indepth interview) merupakan suatu proses mendapatkan informasi untuk kepentingan penelitian, metode yang dilakukan seperti survei yaitu pewawancara bertanya kepada responden dengan harapan untuk 
memperoleh informasi mengenai fenomena yang ingin diteliti. Metode wawancara secara mendalam biasanya dilakukan atas dasar ketertarikan peneliti untuk memperoleh data dan gambaran yang mendalam. Tujuan metode wawancara mendalam yaitu untuk mendapatkan data primer. Data primer merupakan data yang diperoleh secara langsung dari responden. Data primer yang dihasilkan yaitu mengenai modal sosial anggota kelompok tani Gemahripah dalam mengatasi permasalahan hama dan penyakit tanaman di Desa Wirowongso Kecamatan Ajung. Teknik wawancara yang dilakukan dalam penelitian ini yaitu wawancara bebas terpimpin dengan pertanyaan sudah disiapkan dengan arah yang pasti tetapi informan tetap dapat menjawab pertanyaan dengan bebas. Indikator penggunaan metode wawancara yaitu kaitanya dengan kebutuhan dan kejelasan data atau informasi yang akan dibahas, semakin banyak atau semakin mendalam suatu wawancara maka akan semakin banyak pula informasi yang didapat.

\section{Observasi Partisipasi Pasif}

Data primer yang dikumpulkan dari responden juga diperoleh dengan metode observasi partisipasi pasif. Menurut Sugiyono (2014), metode observasi partisipasi pasif merupakan metode observasi dimana peneliti datang di tempat kegiatan orang yang diamati, tetapi tidak ikut terlibat dalam kegiatan tersebut. Metode observasi dilakukan dengan tujuan untuk mengetahui secara langsung modal sosial anggota kelompok tani dalam mengatasi permasalahan hama. Indikator penggunaan metode observasi partisipasi pasif yaitu kaitannya kemurnian data, yang mana peneliti menginginkan data yang murni dari informan tanpa ada pengaruh dari luar.

\section{Dokumentasi}

Menurut Djaelani (2013), teknik pengumpulan data dengan kajian dokumentasi dilakukan dengan cara menyelidiki data yang didapat dari dokumen, catatan, file dan hal-hal yang didokumentasikan. Kajian dokumentasi dilakukan dengan tujuan untuk memperoleh data sekunder. Data sekunder merupakan data yang diperoleh dari berbagai sumber instansi yang terkait dengan penelitian. Data sekunder yang diperoleh dalam penelitian ini yaitu berupa profil Kelompok tani Gemahripah, Toko Pertanian serta data demografis Desa Wirowongso, berdasarkan data tersebut peniliti dapat mengetahui kondisi dan keadaan anggota kelompok tani Gemahripah dalam mengatasi permasalahan hama. Pertimbangan menggunakan kajian dokumentasi kaitanya dengan kelengkapan data, dimana dokumentasi berperan sebagai pelengkap data-data yang diperoleh langsung di lapang.

Analisis data merupakan proses mencari dan menyusun secara sistematis data-data yang diperoleh di lapang. Data-data yang terkumpul dari hasil wawancara, observasi dan dokumentasi dianalisis lebih lanjut dengan tujuan untuk mereduksi datadata tersebut agar lebih mudah dipahami. Metode analisis data yang digunakan dalam penelitian ini yaitu metode analisis data dengan model Miles dan Huberman. Metode ini dipilih guna menelaah data lebih lanjut hingga lebih jelas dan mudah dipahami. Menurut Sitorus et al 
(2015), metode analisis data dengan model Miles dan Huberman dilakukan dengan beberapa tahapan kualitatif, yaitu pengumpulan data, reduksi data, penyajian data, dan pengambilan keputusan atau verifikasi. Model analisis data Miles dan Huberman dapat dilihat pada gambar berikut:

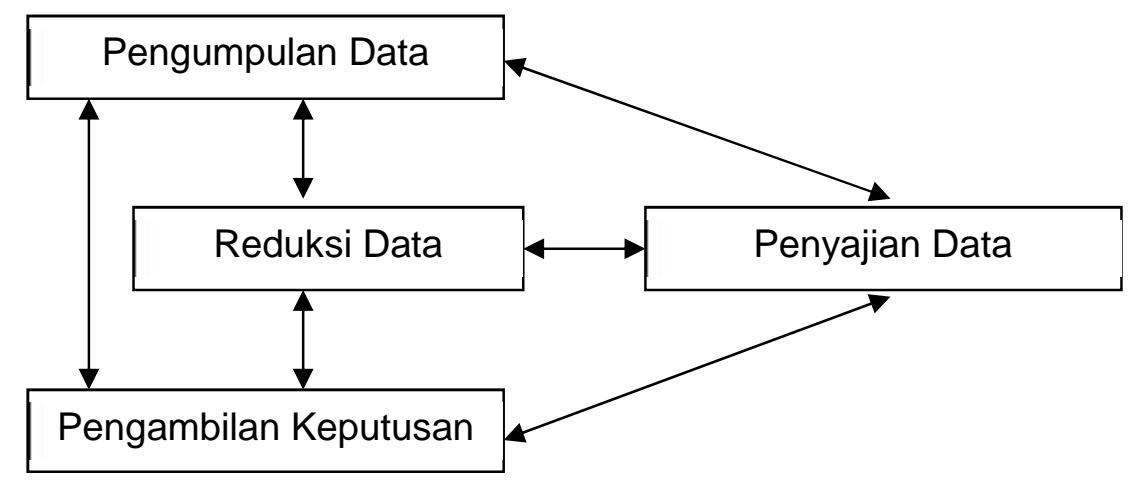

Gambar 1. Model metode analisis data Miles dan Huberman

Sumber : data primer (diolah), 2015

1. Pengumpulan Data

Pengumpulan data yaitu peneliti mencatat semua data secara objektif dan apa adanya berdasarkan hasil observasi dan wawancara yang ada di lapang. Pengumpulan data yang dilakukan guna mendapatkan data primer dan data sekunder menggunakan metode wawancara mendalam, observasi partisipasi pasif, dan dokumentasi mengenai peran modal sosial anggota kelompok tani Gemahripah dalam menghadapi permasalahan hama dan penyakit tanaman. Pengumpulan data merupakan dasar atau tahapan pertama dari metode analisis Miles dan Huberman, yang mana dari pengumpulan data tersebut akan menghasilkan data yang langsung dapat disajikan, atau diproses terlebih dahulu. Data yang telah terkumpul dapat direduksi atau dipilih terlebih dahulu atau dapat langsung diambil keputusan dari data yang ada, tergantung data yang diperoleh apakah sudah tepat sesuai dengan fokus permasalahan atau tidak, jika data sudah dirasa tepat dan layak, maka pengambilan keputusan dapat langsung dilakukan.

\section{Reduksi Data}

Data yang dirasa terlalu kompleks dapat dilakukan proses selanjutnya yaitu proses reduksi data yaitu dengan memilih hal-hal pokok yang sesuai dengan fokus penelitian. Reduksi data merupakan suatu bentuk analisis yang menggolongkan, mengarahkan, membuang yang tidak perlu dan mengorganisasikan datadata yang telah direduksi memberikan gambaran yang lebih tajam tentang hasil pengamatan dan mempermudah peneliti untuk mencarinya sewaktuwaktu diperlukan. Reduksi data dilakukan dengan cara memilih datadata yang berkaitan dengan peran modal sosial anggota kelompok tani Gemahripah dalam menghadapi permasalahan hama dan penyakit tanaman. Data-data yang dipilih diusahakan data yang benar-benar valid dan dapat diterima oleh pembaca. 
3. Penyajian Data

Data yang sudah dipilih atau direduksi terlebih dahulu disajikan sebelum di verifikasi. Penyajian data yaitu sekumpulan informasi tersusun yang ditujukan untuk penarikan kesimpulan dan pengambilan tindakan. Penyajian data merupakan analisis dalam bentuk matrik, network, atau grafis sehingga data dapat dikuasai. Data harus disajikan dengan sejelas-jelasnya agar data tersebut mudah dipahami, selain itu juga menghindari kesalahpahaman. Data yang disajikan dalam penelitian ini antara lain data peran modal sosial anggota kelompok tani Gemahripah dalam menghadapi permasalahan hama dan penyakit tanaman yang didalamnya terdapat unsur-unsur modal sosial antara lain partisipasi, respirocity, trust, norma, nilai dan tindakan proaktif yang didasarkan keterangan dari informan dalam bentuk matrik, sehingga dapat diketahui peran modal sosial yang ada.

4. Pengambilan Keputusan atau Verifikasi

Tahapan yang terakhir yaitu pengambilan keputusan atau verifikasi. Pengambilan keputusan atau verifikasi dilakukan setelah data disajikan, setelah itu dilakukan penarikan kesimpulan atau verifikasi, dalam penarikan kesimpulan atau verifikasi tersebut diperlukan pola, model, tema, hubungan, persamaan dan sebagainya. Verifikasi dapat dilakukan dengan keputusan didasarkan pada reduksi data, dan penyajian data yang merupakan jawaban atas masalah yang diangkat dalam penelitian. Melalui reduksi dan penyajian data tersebut maka nantinya akan diperoleh sebuah keputusan atau kesimpulan sementara mengenai peran modal sosial anggota kelompok tani Gemahripah dalam menghadapi permasalahan hama dan penyakit tanaman. Komponen-komponen dalam analisis data harus saling terkait dan mempengaruhi agar kesimpulan yang diperoleh benarbenar valid.

Penelitian yang baik dapat dipastikan terlebih dahulu diuji keabsahan data yang digunakan, untuk menetapkan keabsahan (trustworthiness) diperlukan teknik pemeriksaan yang didasarkan pada kirteria-kriteria tertentu. Menurut Sugiyono (2014) uji keabsahan data dalam penelitian kualitatif meliputi uji credibility (validitas internal), tranferbility (validitas eksternal), dependability (reablilitas), dan confirmability (objektifitas). Uji keabsahan data yang dilakukan dalam penelitian ini yaitu dengan menggunakan uji kredibilitas data. Kredibilitas data merupakan uji kepercayaan untuk mendapatkan hasil data yang akurat, dalam penelitian kualitatif uji kredibilitas dilakukan dengan triangulasi. Penelitian mengenai modal sosial anggota kelompok tani Gemahripah dalam menghadapi permasalahan hama dan penyakit tanaman diuji kredibilitas atau keabsahan datanya menggunakan teknik triangulasi. Teknik triangulasi diartikan sebagai pengecekan data dari berbagai sumber dengan berbagai cara serta penggunaan waktu yang tepat. Teknik triangulasi yang digunakan pada penelitian ini bertujuan untuk menguji kredibilitas dengan cara mengecek semua data dari berbagai sumber yang diperbandingkan yang disebut triangulasi sumber. 
Triangulasi sumber dilakukan untuk menguji kredibilitas, dengan hasil yang dari pengecekan data tidak dirata-rata namun dideskripsikan, dikategorikan kemudian dilakukan analisis untuk diambil kesimpulan dari data tersebut. Teknik triangulasi sumber dapat dicapai dengan jalan :

a. Membandingkan data hasil pengamatan dengan hasil wawancara.

b. Membandingkan apa yang dikatakan orang didepan umum dengan apa yang dikatakan secara pribadi.

c. Membandingkan apa yang dikatakan orang-orang tentang situasi penelitian dengan apa yang dikatakan sepanjang waktu.

d. Membandingkan keadaaan dan perspektif seseorang dengan berbagai pendapat dan pandangan seperti dalam hal ini ketua kelompok dan anggota kelompok.

Triangulasi sumber yang dilakukan dengan membandingkan informasi yang diperoleh peneliti dari masing-masing informan. Informasi tentang proses peran modal sosial anggota kelompok tani Gemahripah dalam menghadapi permasalahan hama dan penyakit tanaman diperoleh dari hasil wawancara dengan ketua kelompok tani Gemahripah dibandingkan dengan informasi yang diperoleh dari hasil wawancara dengan anggota kelompok tani Gemahripah dan pemilik kios pertanian. Hasil perbandingan tersebut pada akhirnya akan diberikan pandangan sesuai dengan permasalahan penelitian, hal ini dapat digambarkan sebagai berikut:

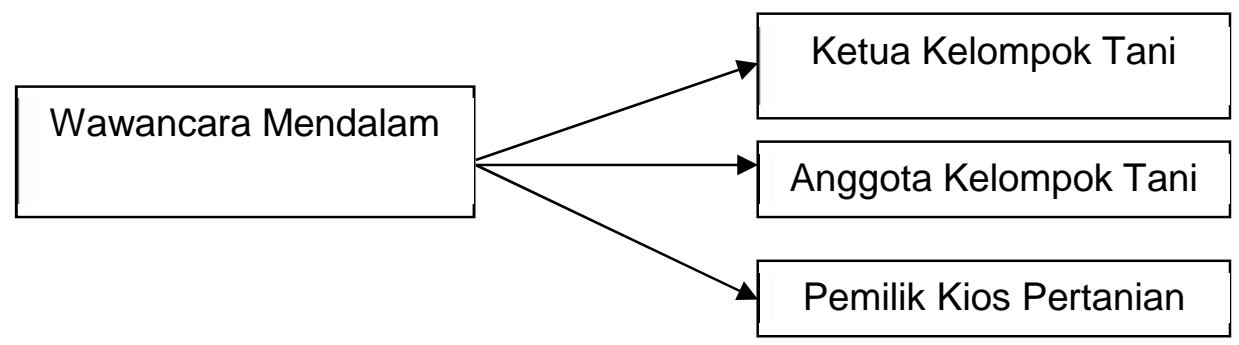

Gambar 2. Triangulasi Sumber

Sumber : data primer (diolah), 2014.

Berikut merupakan beberapa definisi istilah-istilah (terminologi) yang digunakan dalam penelitian :

1. Modal sosial dapat didefinisikan sebagai serangkaian nilai dan norma informal yang dimiliki bersama, diantara para anggota suatu kelompok masyarakat yang memungkinkan terjadinya kerjasama diantara mereka.

2. Kios pertanian merupakan stakeholder yang menjual kebutuhan produksi, dalam penelitian ini juga berperan sebagai pemberi informasi seputar permasalahan hama dan penyakit yang terletak di Desa Rowo Indah atau di luar Desa Wirowongso

3. Informan Kunci merupakan informan utama yaitu mereka yang berpartisipasi atau mempercayai kios pertanian dalam mengatasi permasalahan hama dan penyakit tanaman di Desa Wirowongso. Informan kunci pada penelitian ini adalah 
Ketua Kelompok Tani Gemahripah

4. Informan pendukung merupakan informan yang mendukung dalam memberikan informasi mengenai unsurunsur modal sosial terkait kepercayaan anggota kelompok tani Gemahripah dalam mengatasi permasalahan hama dan penyakit tanaman. Informan pendukung pada penelitian ini ada 2 yaitu anggota kelompok tani dan pemilik kios pertanian

5. Ketua Kelompok Tani Gemahripah merupakan pimpinan kelompok tani yang bertanggung jawab atas kelompok, juga merupakan informan kunci yang dapat memberikan informasi sejelasjelasnya mengenai modal sosial anggota kelompok tani Gemahripah dalam mengatasi permasalahan hama dan penyakit tanaman.

6. Anggota kelompok tani Gemahripah merupakan individu-individu yang berada dan berinteraksi di dalam kelompok. Anggota kelompok tani berperan sebagai informan pendukung.

7. Pemilik kios pertanian merupakan seseorang yang menjual sarana produksi pertanian yang terletak di luar Desa Wirowongso, yang dipercaya oleh kelompok tani Gemahripah dalam mengatasi permasalahan hama dan penyakit tanaman.

8. Unsur-unsur modal sosial antara lain partisipasi, resipirocity, trust, norma sosial, nilai dan tindakan proaktif.

9. Metode penelitian menggunakan penelitian kualitatif, dimana penelitian ini bersifat sosial yang berlatar belakang alamiah dan memahami suatu fenomena yang ada dilapang yaitu modal sosial anggota kelompok tani Gemahripah dalam mengatasi hama dan penyakit tanaman

10. Metode penelitian dijelaskan menggunakan metode analisis kualitatif dan studi kasus yang merupakan metode dengan menggambarkan secara jelas fakta-fakta dan kasus yang ada di lapang terkait modal sosial anggota kelomok tani Gemahripah dalam mengatasi permasalahan hama dan penyakit.

11. Purposive method merupakan teknik penentuan daerah penelitian secara sengaja oleh peneliti dengan kriteria atau pertimbangan yang telah ditentukan sebelumnya.

12. Purposive sampling meupakan teknik penentuan sumber informasi atau informan yang dilandasi tujuan dan pertimbangan tertentu telebih dahulu..

13. Pengumpulan data pada penelitian ini menggunakan metode wawancara mendalam, observasi partifipasi pasif dan dokumentasi.

14. Metode analisis data yang digunakan yaitu dengan model Miles dan Huberman antara lain pengumpulan data, reduksi data, penyajian data, dan pengambilan keputusan atau verifikasi.

15. Uji keabsahan data yang dilakukan dalam penelitian ini yaitu dengan menggunakan uji kredibilitas data. Kredibilitas data merupakan uji kepercayaan untuk mendapatkan hasil data yang akurat. 
16. Triangulasi sumber merupakan pengecekan data dari berbagai sumber dengan berbagai cara serta penggunaan waktu yang tepat.

\section{HASIL DAN PEMBAHASAN}

Kelompok tani Gemahripah merupakan kelompok tani yang berada di Desa Wirowongso Kecamatan Ajung Kabupaten Jember. Desa Wirowongso sebagai daerah penelitian memiliki karakteristik tersendiri. Desa Winowonso merupakan desa yang terletak di daerah perkotaan, namun masih memiliki potensi di bidang pertanian. Desa Winowngso dalam kegiatan pertaniannya memiliki permasalahan hama dan penyakit tanaman. Penduduk desa tersebut mengatasi permasalahan tersebut secara individu.

Modal sosial anggota Kelompok Tani Gemahripah diawali dari adanya kepercayaan yang timbul kepada kios pertanian Sumber Dadi yang terletak di Desa Rowo Indah, yang mana kepercayaan tersebut didasari dari adanya permasalahan hama dan penyakit yang cenderung tak mampu diselesaikan oleh petani. Turunnya keaktifan kelompok tani turut diikuti dengan jarang berkumpulnya kelompok sehingga mengakibatkan informasi yang didapat petani lebih sedikit, dan hal ini memaksa anggota kelompok tani mencari informasi dari berbagai sumber dalam kegiatan usaha taninya. Permasalahan yang kerap kali menyerang usaha tani anggota Kelompok Tani Gemahripah yaitu permasalahan hama dan penyakit, yang kerap kali petani tak mampu mengatasinya karena kekurangan informasi baik dari kelompok ataupun PPL setempat. Ketidakaktifan Kelompok Tani Gemahripah tidak serta merta dibiarkan begitu saja oleh ketua kelompok tani. Ketua kelompok tani masih bertanggung jawab terhadap anggotanya sehingga mencari informasi seputar permasalahan yang pada akhirnya memilih kios pertanian Sumberdadi yang terletak di Desa Rowo Indah, kepercayaan atau trust timbul seiring berjalanya waktu, seiring dengan informasi dan solusi yang diberikan oleh pemilik kios pertanian Sumberdadi. Kepercayaan merupakan salah satu unsur modal sosial, tak hanya itu dari adanya kepercayaan diikuti dengan unsurunsur modal sosial lainya. Unsurunsur modal sosial menjadi penanda setiap hubungan yang terjalin antara anggota kelompok tani dengan kios. Modal sosial anggota kelompok tani Gemahripah dalam mengatasi permasalahan hama dan penyakit antara lain;

\section{Partisipasi dalam Jaringan} Partisipasi dalam jaringan pada dasarnya merupakan kegiatan masyarakat yang selalu berhubungan sosial dengan masyarakat lain melalui variasi hubungan yang saling berdampingan yang pada dasarnya bertujuan untuk menyatukan diri dalam suatu pola hubungan yang sinergis akan sangat besar pengaruhnya dalam menentukan kuat tidaknya modal sosial suatu kelompok. Partisipasi dalam jaringan antara anggota kelompok tani dengan kios pertanian Sumberdadi dilakukan dengan tujuan untuk menyatukan diri dalam suatu pola hubungan yang sinergis antar anggota kelompok dan kios pertanian guna mengatasi permasalahan hama dan penyakit. Partisipasi dari kios pertanian dalam jaringan antara kios dengan anggota kelompok tani dilakukan dengan cara memberikan fasilitas baik membagikan informasi ataupun fasilitas berbentuk obat guna mengatasi permasalahan hama dan 
penyakit. Partisipasi dalam jaringan anggota Kelompok Tani Gemahripah dalam mengatasi permasalahan hama dan penyakit tak hanya dilakukan dengan kios tetapi juga dilakukan antara anggota dalam kelompok. Partisipasi yang kuat didalam suatu kelompok akan mempermudah untuk mengatasi permasalahan hama dan penyakit.

2. Respirocity atau Timbal Balik Modal sosial anggota Kelompok Tani Gemahripah dalam mengatasi hama dan penyakit tanaman yang kedua yaitu respirocity atau timbal balik. Modal sosial senantiasa diwarnai oleh kecenderungan saling tukar kebaikan antar individu dalam suatu kelompok atau antar kelompok itu sendiri, pada masyarakat dan kelompok-kelompok sosial yang terbentuk di dalamnya memiliki bobot resiprositas kuat akan melahirkan suatu masyarakat yang memiliki tingkat keuntungan lain sehingga masyarakat tersebut lebih mudah dalam membangun diri. Respirocity yang terlihat yaitu antara anggota Kelompok Tani Gemahripah dengan kios pertanian Sumberdadi. Respirocity atau timbal balik yang dilakukan antara anggota ataupun dengan kios pertanian dilakukan dengan cara sharing informasi dan saling memberi masukan baik dari petani ataupun dari kios pertanian, yang mana dari keduanya sama-sama belajar dan terbuka akan masukan. Kepercayaan akan kios yang dilakukan oleh anggota Kelompok Tani Gemahripah dibalas atau mendapatkan timbal balik berupa perhatian yang lebih dari kios terutama pemilik Kios Pertanian Sumber Dadi yaitu Pak Sudibyo. Perhatian yang lebih diberikan dengan terus menanyakan kondisi lahan yang terkena hama dan penyakit serta membuka ruang atau menerima konsultasi jika hama dan penyakit terus menerus menyerang.

\section{Trust atau Kepercayaan}

Modal sosial selanjutnya yang ada pada anggota Kelompok Tani Gemahripah dalam mengatasi hama dan penyakit tanaman merupakan modal sosial yang merupakan dasar dari keberlanjutan hubungan antar anggota kelompok dan dengan kios pertanian yaitu trust atau kepercayaan. Trust adalah sikap saling mepercayai di masyarakat yang memungkinkan masyarakat tersebut saling bersatu dengan yang lain dan memberikan kontribusi pada peningkatan modal sosial. Kepercayaan menjadi dasar utama hubungan anggota kelompok tani dengan kios pertanian, karena dengan adanya rasa saling percaya hubungan menjadi lebih menyatu dan berkelanjutan. Kepercayaan anggota Kelompok Tani Gemahripah terhadap Kios Pertanian Sumber Dadi timbul karena adanya perlakuan yang lebih didapatkan petani. Perlakuan tersebut berupa pelayanan yang tidak biasa antara penjual dan pembeli, pemilik kios tak hanya menjual obat-obatan atau pestisida tetapi juga berbagi ilmu dan membantu petani sehingga memberikan kemudahan dalam mengatasi hama dan penyakit. Kebaikan pemilik kios membuat petani betah dan mempercayai Kios Pertanian Sumberdadi dibanding dengan kios pertanian lainya

\section{Norma Sosial}

Modal sosial anggota Kelompok Tani Gemahripah dalam mengatasi permasalahan hama dan penyakit selanjutnya yaitu norma sosial. Norma merupakan sekumpulan aturan yang diharapkan dipatuhi dan diikuti oleh anggota masyarakat pada suatu aktivitas sosial tertentu. Norma sosial yang dijaga juga berkaitan dengan tindakan dalam pengendalian yang 
mana berkaitan dengan ketertiban dalam penjadwalan penyemprotan serta kesesuaian penerapan pengendalian yang dilakukan petani dengan aturan atau anjuran kios pertanian. Norma sosial anggota Kelompok Tani Gemahripah dalam mengatasi permasalahan hama dan penyakit tanaman salah satunya dengan menjaga ketertiban atau kesesuaian penjadwalan penyemprotan bisa dilakukan massal atau individu, penentuan tanggal dan hari jadwal penyemprotan berguna untuk mengajak anggota Kelompok Tani Gemahripah turut ikut serta berperan aktif dalam penyemprotan massal atau individu, norma tidak tertulis tetapi dipahami oleh anggota kelompok tani Gemahripah

\section{Nilai-nilai}

Nilai-nilai merupakan salah satu unsur modal sosial yang melekat dan ada di masyarakat merupakan sesuatu ide yang telah turun temurun dianggap benar dan penting oleh anggota kelompok masyarakat, sesuatu dikatakan memiliki nilai apabila mempunyai kegunaan, kebenaran, kebaikan, keindahan dan religiositas. Nilai-nilai dalam modal sosial anggota kelompok tani Gemahripah dalam menghadapi permasalahan hama dan penyakit tanaman yaitu berkaitan dengan apa yang dianggap baik oleh petani, mulai dari tingkah laku, ide ataupun kepribadian dari subjek yaitu kios pertanian. Petani memiliki penilaian tersendiri terhadap pemilik kios, penilaian terhadap kios menjadi salah satu aspek nilai karena petani beranggapan bahwa pemilik kios merupakan orang yang baik dan sangat berguna bagi petani, selain itu nilai-nilai yang dipegang oleh petani berkaitan dengan penentuan informasi dalam pengendalian hama dan penyakit.

\section{KESIMPULAN}

Modal sosial anggota kelompok tani Gemahripah dalam mengendalikan hama dan penyakit tanaman dapat dilihat dari 5 unsur utama antara lain partisipasi dalam jaringan. Partisipasi dalam jaringan dilakukan oleh antar anggota kelompok tani atau dengan kios pertanian yaitu dengan saling sharing informasi atau dengan memberikan fasilitas baik berupa ilmu atau materi. Respirocity atau timbal balik yang dilakukan antara anggota ataupun dengan kios pertanian dilakukan dengan cara sharing informasi dan saling memberi masukan baik dari petani ataupun dari kios pertanian. Trust atau kepercayaan anggota Kelompok Tani Gemahripah terhadap Kios Pertanian Sumber Dadi timbul karena adanya perlakuan yang lebih didapatkan petani. Kepercayaan juga diberikan oleh kios kepada petani dalam penyebarluasan informasi juga sebagai pembeli. Norma sosial yang selama ini dijaga oleh anggota Kelompok Tani Gemahripah maupun Kios Pertanian Sumber Dadi dalam mengatasi permasalahan hama dan penyakit berkaitan dengan keterbukaan untuk sharing informasi dan aturan berkaitan dengan pengendalian hama penyakit. Nilainilai dalam modal sosial anggota kelompok tani Gemahripah dalam menghadapi permasalahan hama dan penyakit tanaman yaitu berkaitan dengan apa yang dianggap baik oleh petani, mulai dari tingkah laku, ide ataupun kepribadian dari subjek yaitu kios pertanian serta dalam pemilihan informasi dalm mengatasi permasalahan hama dan penyakit.

\section{DAFTAR PUSTAKA}

Djaelani, A. R. (2013). Teknik Pengumpulan Data dalam Penelitian Kualitatif. Majalah 
Ilmiah Pawiyatan Volume XXNomor 31., 82-92.

Gumilang, S.G. 2016. Metode Penelitian Kualitatif dalam Bidang Bimbingan dan Konseling. Jurnal Fokus Konseling. 2(2):144-159.

Kimbal, R.W. 2015. Modal Sosial dan Ekonomi Industri Kecil: Sebuah Studi Kualitatif. Yogyakarta: Dee Publisher.

Luciana, S., Margadinata, R., Bisnis, P. M., Manajemen, P. S., Petra, U. K., \& Siwalankerto, J. (2017). Analisis Penerapan Modal Sosial Pada Pt . Rajawali Inti Probolinggo, 5(1).

Maer, M.N.D. 2008. Pengantar Teori Komunikasi. Jakarta: Salemba Humanika.

Rianse, U. dan Abdi. 2012. Metodologi Penelitian Sosial Ekonomi Teori dan Aplikasi. Bandung:Alfabeta

Soepriadi, D. S. dan I. F. (2014). Modal_Sosial_Petani_dan_Perke mbangan_Industri_di_D. Jurnal Perencanaan Wilayah Dan Kota Vol. 25, No. 1, Hlm. 17-36, 25(1), 17-37.

https://doi.org/10.5614/jpwk. 2014.25.1.2

Sitorus, S., L. Kalangi, dan S. K. Walandouw. 2015. Analisis Kesiapan Penerapan Standar Akuntansi Pemerintah Berbasis Akrual Berdasarkan PP. No. 71 Tahun 2010 pada Dinas Pendapatan Pengelolaan Keuangan dan Barang Milik Daerah Kota Tomohon. EMBA, 3(1): 941-949.
Sugiarto, E. 2015. Menyusun Proposal Penelitian Kualitatif : Skripsi da Tesis.Yogyakarta : Suaka Media

Sugiyono. 2014. Metode Penelitian Pendidikan. Bandung: Alfabeta.

Surachman, E., Suryanto, W.A. 2010. Hama dan Penyakit Tanaman Pangan, Hortikultura dan Perkebunan Masalah dan Solusinya. Yogyakarta : Kanisius.

Suwendra, I.W. 2018. Metodologi Penelitian Kualitatif dalam Ilmu Sosial, Pendidikan, Kebudayaan dan Keagamaan. Bali : Nilacakra.

Trisnanto, T. B., Fitriani, \& Fatih, C. (2017). Building social capital for farmer association. Masyarakat, Kebudayaan Dan Politik, 30(10), 59-67. Retrieved from http://ejournal.unair.ac.id/index.php/ $\mathrm{MKP} /$ article/viewFile/2621/27 $\underline{18}$

Wastika, C. Y., Hariadi, S. S., Pertanian, F., \& Gadjah, U. (2014). PERAN KELOMPOK TANI DALAM PENERAPAN SRI ( SYSTEM OF RICE INTENSIFICATION ) DI KECAMATAN KALIKAJAR KABUPATEN WONOSOBO The Role of Farmer Group in The Application of SRI ( System of Rice Intensification ) in Kalikajar Subdistrict Wonosobo Regency, 24(1).

Yusuf, M. A. 2014. Metode Penelitian : Kuantitatif, Kualitatif dan Penelitian Gabungan. Jakarta : Kencana. 